\title{
Immigration and Identity in the Middle Ages : French Immigrants to Constantinople and Greece in the Thirteenth Century
}

Erica Jo Gilles

\section{(2) OpenEdition \\ 12 Journals \\ Édition électronique \\ URL : https://journals.openedition.org/cem/418 \\ DOI : $10.4000 /$ cem. 418 \\ ISSN : 1954-3093 \\ Éditeur \\ Centre d'études médiévales Saint-Germain d'Auxerre}

\section{Édition imprimée}

Date de publication : 15 août 2006

ISSN : 1623-5770

Référence électronique

Erica Jo Gilles, «Immigration and Identity in the Middle Ages: French Immigrants to Constantinople and Greece in the Thirteenth Century », Bulletin du centre d'études médiévales d'Auxerre I BUCEMA [En ligne], 10 | 2006, mis en ligne le 08 septembre 2006, consulté le 22 septembre 2022. URL : http:// journals.openedition.org/cem/418; DOI : https://doi.org/10.4000/cem.418

Ce document a été généré automatiquement le 22 septembre 2022.

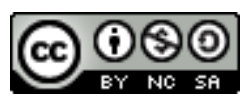

Creative Commons - Attribution - Pas d'Utilisation Commerciale - Partage dans les Mêmes Conditions 4.0 International - CC BY-NC-SA 4.0

https://creativecommons.org/licenses/by-nc-sa/4.0/ 


\title{
Immigration and Identity in the Middle Ages : French Immigrants to Constantinople and Greece in the Thirteenth Century ${ }^{1}$
}

\author{
Erica Jo Gilles
}

1 After capturing Constantinople in 1204, the Fourth Crusaders established several states in former Byzantine territory. Starting from the captured imperial center, westerners moved into Thrace, Greece, the Aegean islands, and even Asia Minor. These campaigns of conquest had varied success, with the greatest and longest lasting in southern Greece $^{2}$. The Fourth Crusaders had struck out for the east as warriors, not as immigrants, and after a year, many of them returned to their homelands. Some remained, however, to establish their rule over indigenous populations and to defend their new territory. These settlers brought relatives from the west, formed marriage alliances for themselves and their children in the east, and reoriented their lives towards ruling and defending their newly conquered lands. For these immigrants, and later ones, their new commitments meant leaving family, political relationships, and lands in the west for an uncertain future in an unfamiliar land. My dissertation deals with these immigrants and, more broadly, with questions of immigration and identity in the Middle Ages.

2 These immigrants were exceptional. In the thirteenth century, crusading, although a major, risky and expensive enterprise, was not an unusual activity for French aristocracy. Many families had traditions of crusading going back to the first crusade and histories of involvement in the Holy Land before that ${ }^{3}$. Brothers, fathers and sons, uncles and nephews, took the cross together. Of the many crusaders, however, the vast majority returned home or died on crusade. Only a few built lives in conquered lands abroad. It is these few who concern me.

3 Of the settlers we can identify, a number of them heralded from Champagne and Burgundy. Family names such as Courtenay, Toucy, Champlitte, Brienne, Villehardouin, 
Merry, La Roche, and Aulnay will be familiar to scholars of these areas. The archives of Champagne and Burgundy, including the Archives départmentales de l'Yonne, hold tantalizing hints to the lives and outlooks of thirteenth century immigrants to Greece and their descendants.

The Courtenays, based in Auxerre, emperors-in-residence at Constantinople from 1217 to 1261 and titular emperors thereafter, are an elite example of an immigrant family. I provide a brief summary of their history here in order to highlight themes that have arisen in my study of immigrants to the east ${ }^{4}$. After the death of Henry of Hainaut, emperor of Constantinople, a delegation of nobles from Constantinople traveled to the west to offer the crown to Peter of Courtenay and his wife, Yolanda, who was the sister of Henry and Baldwin, the first two emperors. Perhaps the first question relevant to this study is why they went. Peter and Yolanda's son-in-law, Andre, the king of Hungary, had already turned down the crown. Their son, Philip of Namur, would turn it down as well a few years later. The lives of Peter and Yolanda are well-documented in the Auxerre archives. Seeking the answer in these documents, however, is a frustrating endeavor. Involved in politics, conflicts with religious institutions, and the management of their lands, Peter and Yolanda's departure for the east marked a strong break from their previous engagement with French concerns. No documents survive which explain why they chose to accept the imperial crown. Peter had demonstrated interest in the east previously, joining Philip Augustus on the Third Crusade and Yolanda had close family ties to the previous emperors. But these did not make them unique. By 1216, Peter's sometimes tendentious relationship with the bishop of Auxerre had eased; however, much of the territory under Peter's control had been the inheritance of his first wife, Agnes. When their daughter, Mathilda, married Hervé of Donzy, some lands transferred with her. The rest of Agnes's inheritance would go to Mathilda upon Peter's death. Peter may have been motivated by a desire to arrange inheritance for his sons or to have lands of his own. Yolanda may have been drawn to the empire of her brothers. As with many immigrants, we can identify certain factors that may have predisposed them to migration, but it is difficult to ascertain precisely what the tipping point was. Peter never enjoyed the imperial throne. He and Yolanda were crowned outside of Rome in April 1217, but he was captured and killed en route to Constantinople. One of Peter's sons, Robert, came from the west to succeed his parents. His older brother, Philip of Namur, had refused the crown. Although the archives hold little record of Robert, as a younger son with little territory and power in the west, the appeal of an imperial crown may have been greater for him than for his brother, already a powerful lord.

5 The Courtenays in the east, specifically Yolanda and her children Robert, Marie, Agnes and Baldwin, clearly shifted their focus to eastern territories although retaining political links to the west. This shift can be seen immediately in Yolanda's marriage arrangements for her daughters. Two of them came on the voyage to Constantinople. En route, Agnes was married to Geoffrey of Villehardouin, the eldest son and heir of the prince of the Morea and a member of an important Champagnois family. Once in Constantinople, a marriage was arranged between Marie and Theodore Lascaris, a rival Greek emperor in Nicaea. With these two marriages, Yolanda created alliances with a powerful ally, the Villehardouin, and a powerful enemy, the emperor of Nicaea. These types of marriage alliances, creating bonds between allies and tentative peace with 
enemies, were common in the history of Frankish Greece and demonstrate a focus on protecting the territory of the new empire.

Despite these eastern marriage alliances, the Courtenays did not lose their connections to the west. In 1221, Peter and Yolanda's son Robert arrived to take the imperial crown. Evidence from the first ten years of Courtenay rule in Constantinople is sparse. After the death of Robert in 1228, however, the barons of the Latin Empire sought a regent to rule until Baldwin, born to Yolanda after her arrival in Constantinople, achieved his majority. John Asen, the Bulgarian tsar, proposed an alliance between his daughter and Baldwin, but the barons turned instead to the west and John of Brienne, former king of Jerusalem, count of Brienne, and a close ally of the pope. During John's reign, Baldwin made his first visit to the west seeking aid. In this visit he established close relations with the French royal family which he would maintain throughout his life. Louis IX and Blanche proffered advice to Baldwin through correspondence and he turned to them to facilitate his dealings with western lands and relatives. Eventually, after his exile from Constantinople in 1261, Baldwin made an alliance with Charles of Anjou through the marriage of Baldwin's son and heir Philip and Beatrice of Anjou. No serious attempt was ever made to retake Constantinople, but Baldwin saw the Angevins, with their close relationship to the kings of France and their base in southern Italy and Sicily, as his best chance of regaining his lands.

7 While Baldwin relied on the French royal family for advice and support, his interests were tied up in the east. Baldwin attempted to alienate Courtenay to Geoffrey of Villehardouin, but Louis IX refused to approve of the transfer of Baldwin's ancestral land. Baldwin then assigned Courtenay to his wife, Marie of Brienne. Baldwin exhibited no interest in returning to his French or Flemish patrimony after his exile from Constantinople. The Courtenays were not alone in this. By 1261, the Courtenays and other nobles of the Latin Empire and Greece were oriented towards their eastern lands. Once exiled, the elite of the Latin Empire moved primarily to Italy and Greece, remaining focused on eastern or at least Mediterranean enterprises.

8 This brief and incomplete history of the Courtenays suggests some of the questions which arise in a study of French immigrants to Greece and Constantinople : motivations for immigration, realigned priorities as expressed through marriage alliances and land transactions, continued personal and political ties with important families in the west, and the post-exile struggle to recover lost territory in the east. The Courtenays and other individuals in their political and familial network turned to the east in the thirteenth century and sought their futures there. The story of these immigrants and their descendants will speak to the larger questions surrounding medieval immigration. 


\section{NOTES}

1. E. J. Gilles is a doctoral student in medieval history at Princeton University, working under the direction of Professor William Chester Jordan. She conducted research in Auxerre for several months in 2005 and 2006.

2. A. BON, La Morée franque : recherches historiques, topographiques et archéologiques sur la principauté d'Achaïe (1205-1430), Paris, 1969 ; P. Lоск, The Franks in the Aegean, 1204-1500, London, 1995 ; J. LONGNON, L'empire latin de Constantinople et la principauté de Morée, Paris, 1949 ; William MILLER, The Latins in the Levant : A History of Frankish Greece (1204-1566), London, 1908.

3. J. LONGNON, «Les Toucy en Orient et en Italie au treizième siècle », in Bulletin de La Société des Sciences Historiques et Naturelles de l'Yonne (1953-56), p. 3-11 ; J. RILEY-SMITH, The First Crusaders, 1095-1131, Cambridge, 1997 ; E. SIDBERRY, « The Crusading Counts of Nevers ", Nottingham Medieval Studies, XXXIV (1990), p. 64-71.

4. For the basic story of the Courtenay family see the following: J. DU BOUCHET, Histoire généalogique de la maison royale de Courtenay, Paris, 1661 ; Ch. DU CANGE, Histoire de l'empire de Constantinople sous les empereurs français jusqu'à la conquête des turcs, éd. J. A. C. BUCHON, 2 vol., Paris, 1826 (Collection des chroniques nationales françaises, écrites en langue vulgaire du treizième au seizième siècle, 1-2) ; J. LONGNON, L'empire latin, op. cit.;

A. SAUNIER-SËTTÉ, Les Courtenay : destin d'une illustre famille bourguignonne, Paris, 1998. 